\title{
Chemical and Electro-coagulation Techniques in Coagulation- Floccculation in Water and Wastewater Treatment- A Review
}

\author{
Ukiwe L.N. ${ }^{1^{*}}$, Ibeneme S. $I^{2}$, Duru C.E. ${ }^{3}$, Okolue B.N. ${ }^{4}$, Onyedika G.O. ${ }^{5}$, Nweze C.A. ${ }^{6}$ \\ ${ }^{1,4,5,6}$ Department of Chemistry, Federal University of Technology, Owerri, Nigeria \\ ${ }^{2}$ Department of Geosciences, Federal University of Technology, Owerri, Nigeria \\ ${ }^{3}$ Department of Chemistry, Alvan Ikoku Federal College of Education, Owerri, Nigeria
}

Corresponding author: luggil2002@yahoo.com

\begin{abstract}
Chemical and electrocoagulation are widely used coagulation methods employed in water and wastewater treatment. Both coagulation processes are effective in removing a wide range of impurities which include dissolved organic matter in form of chemical and biological oxygen demand, pathogens, oils, and colloidal particles as well as heavy metals. The present review has revealed that the mode of action of both coagulation methods is based on charge neutralization and floc formation. The effectiveness of both coagulation techniques depend on factors such as $\mathrm{pH}$, coagulation dose, coagulant type, current density, applied voltage, water and wastewater type, type of electrode, as well as size and number of electrodes. The commonly used chemical coagulants are inorganic coagulants based on aluminum and iron salts. However, there have been considerable successes in the development of pre-hydrolyzed inorganic coagulants which have the added advantage over traditional inorganic coagulants in that they function well over a wide range of $\mathrm{pH}$ and water temperatures. Electrocoagulation has been proposed as an alternative method to chemical coagulation because it is environmental friendly and cheap to operate. Nonetheless, most researchers are of the opinion that there are still some uncertainties regarding the understanding of its optimal performance and design mechanism.
\end{abstract}

\section{Indexing terms/Keywords}

Alum; electrolyte; environment; microflocs; oxidizing; parameters; turbidity.

\section{Academic Discipline And Sub-Disciplines}

Environmental chemistry

\section{SUBJECT CLASSIFICATION}

Chemistry

TYPE (METHOD/APPROACH)

Library analysis

\section{Council for Innovative Research}

\author{
Peer Review Research Publishing System
}

Journal: Journal of Advances in Chemistry

Vol. 9, No. 3

editorjaconline@gmail.com

www.cirworld.org/journals 


\subsection{INTRODUCTION}

Coagulation-flocculation process is employed in separating suspended solids materials in water and wastewaters. The process operate in steps which break down forces which stabilize charged particles present in the water or wastewater allowing inter-particle collision to occur, hence, generating flocs. The chemistry of coagulation-flocculation is developed from electricity. Electricity describes the behaviour of charged particles given their attraction/repulsion tendencies. Suspended solids posses negative charge in water. Since their surface charge is the same, they tend to stabilize and repel one another when they come close to one another. The coagulation-flocculation process aim to destabilize the charged particles of suspended solids. Proper application of the process take into account adequate understanding of certain interaction factors which include the source of the charge, composition of the charge, particle size, shape, and density of the suspended particles. Addition of coagulants with charges opposite those of the suspended particles is the first approach to destabilize the particles' charge. Coagulants are added to water and wastewater to neutralize the negative charge of suspended particles. Upon neutralization, the suspended particles stick together to form slightly larger particles. Rapid mixing to effectively disperse the coagulant and encourage particle collision is applied for efficient coagulation. This process is followed by a flocculation process where gentle mixing increases the particle size from sub-microfloc to visible suspended solids. Particles are thus bound together to produce larger macroflocs. To prevent the macroflocs from shearing, careful attention is given to the mixing velocity and energy. The mixing velocity and energy are abated when there appear to be an increase in floc formation.

\section{COAGULANT APPLICATION}

Selecting a coagulant for treatment of water and wastewaters is a function of several factors which include the nature of the suspended particles, raw water and wastewater condition, design of treatment facility, cost of coagulant chemicals, zeta potential (the amount of repulsive forces which ensure that particles stay in water environment), and Van der Waal's forces (weak inter-molecular forces that influence particle formation). Plant scale evaluation analysis or 'jar testing' is performed to select appropriate coagulants for the treatment process. For any treatment process to be effective, attention must be paid to required effluent quality, sludge handling disposal cost (most coagulants generate sludge), and overall dosage cost of coagulant.

\subsection{Coagulant Types}

There are two main types of coagulant chemicals. These include; primary coagulants and coagulant aids. Primary coagulants are involved in neutralizing electrical charges of suspended solids in water, while coagulant aids increases the density of slow-settling flocs by impacting toughness to the flocs to avoid shearing during mixing and settling processes. Coagulant chemicals are either inorganic metallic salts or polymers. Polymers are of three types namely; cationic polymers (positively charged), anionic polymers (negatively charged), and non-ionic (neutrally charged).

\subsection{Chemical Coagulants}

\subsubsection{Pre-polymerized Inorganic Coagulants}

Aluminum (Al) and iron (Fe) salts are the most commonly used form of pre-polymerized inorganic coagulants. In water, these metallic salts produce highly charged ions in form of inorganic hydroxides that neutralize the suspended particles in water. Short polymers which form microflocs are thus produced. Equations depicting the above process are shown below:

$$
\begin{aligned}
& \mathrm{Al}_{2}\left(\mathrm{SO}_{4}\right)_{3}+3 \mathrm{Ca}\left(\mathrm{HCO}_{3}\right)_{2} \rightarrow 2 \mathrm{Al}(\mathrm{OH})_{3}+3 \mathrm{CaSO}_{4}+6 \mathrm{CO}_{2} \\
& \mathrm{Fe}_{2}\left(\mathrm{SO}_{4}\right)_{3}+3 \mathrm{Ca}\left(\mathrm{HCO}_{3}\right)_{2} \rightarrow 2 \mathrm{Fe}(\mathrm{OH})_{3}+3 \mathrm{CaSO}_{4}+6 \mathrm{CO}_{2} \\
& \mathrm{FeSO}_{4}+\mathrm{Ca}\left(\mathrm{HCO}_{3}\right)_{2} \rightarrow \mathrm{Fe}(\mathrm{OH})_{2}+\mathrm{CaSO}_{4}+2 \mathrm{CO}_{2} \\
& 2 \mathrm{FeCl}_{3}+3 \mathrm{Ca}\left(\mathrm{HCO}_{3}\right)_{2} \rightarrow 2 \mathrm{Fe}(\mathrm{OH})_{3}+3 \mathrm{CaCl}_{2}+6 \mathrm{CO}_{2}
\end{aligned}
$$

The effectiveness of $\mathrm{Al}$ and $\mathrm{Fe}$ coagulants is based on their ability to form multi-charged polynuclear complexes with enhanced adsorption characteristics. In a typical coagulation process, the appropriate dose of inorganic salt is added directly to the water or wastewater. At a pH range of approximately 6.5-8.0, extreme hydrolysis occurs. The hydrolysis product may interact chemically with dissolved substances in the raw water leading to hydroxide precipitation when the $\mathrm{pH}$ is less than 6.0. This phenomenon worsens the water quality since restabilization of colloidal particles occurs due to charge reversal. To avoid extreme hydrolysis, 
inorganic coagulants are partially hydrolysed prior addition to water. This process enables the chemistry of the coagulant to be monitored and preferred conditions for the formation of optimal preformed polymeric coagulant species are obtained. Pre-polymeric coagulants are effective over a wide $\mathrm{pH}$ range and are stable to changes in the temperature and nature of the wastewater.

Recent advances in inorganic pre-polymeric coagulants have been extensively published by [1],[2],[3]. More recently, a new kind of pre-polymeric inorganic coagulant have been developed [4],[5],[6]. Inorganic prepolymeric coagulants have the added advantage over traditional classic coagulant chemicals such as Al and Fe salts in that they are more effective over a wide range of $\mathrm{pH}$ and temperature and relatively lower in cost [1]. It has been reported that preformed inorganic polymeric coagulants are successful in remedying certain difficulties associated with seasonal changes in surface water quality often encountered by ordinary inorganic metal salts [7],[8],[9],[10]. Wang and Tang [11] had recently noted that the coagulation behaviour of modified inorganic pre-polyferric silicate coagulant is mainly depended on the kind of silica introduced in the preparation of the coagulant and the silica-iron ratio adopted. In a separate study, Tzoupanos and Zouboulis [12] revealed that the use of silica in the form of polysilicates is a novel development in the category of effective coagulants in removing inorganic and organic particulate matter and pathogens from wastewater. Further studies on polysilicates have been extensively documented by [13] and [14] who evaluated and characterized metal and aluminium-silicate polymer composite as coagulant of choice for treatment of wastewaters. However, Zouboulis and Tzoupanos [15] suggested that polyaluminum silicate chloride is an effective chemical reagent for the preparation of coagulant for treating water and wastewaters. Several authors have also documented that polyaluminum silicate chlorides are effective in turbidity removal and post treatment of landfill leachate [16],[17],[18]. Further contributions on the application of polyaluminum silicate chloride for wastewater treatment has been demonstrated in studies relating to its preparation and characterization [19],[20], and its chemical species distribution [21]. Generally, researchers involved in the development of pre-hydrolyzed inorganic coagulants have developed aluminium, iron, and silica blends to produce effective hydrolysis species not-withstanding process conditions during the water treatment process. This effort has seen advances in the development of pre-hydrolyzed inorganic coagulants such as aluminium chlorohydrate, polyaluminum chloride, polyaluminum sulphate chloride, forms of polyaluminum chloride, and polyferric sulphate.

\subsubsection{Inorganic Metal Coagulants}

The use of inorganic metal salts for coagulation-flocculation has been well documented. Kushwaha et al. [22] had investigated the use of inorganic metal coagulants such as aluminium sulphate (alum) and ferrous sulphate $\left(\mathrm{FeSO}_{4}\right)$ in the treatment of simulated dairy wastewater. The study noted that at optimal pH (8.0), 69.2 and $66.5 \%$ removal efficiency for chemical oxygen demand (COD) was observed using 800 and 500 $\mathrm{mg} / \mathrm{L}$ of $\mathrm{FeSO}_{4}$ and alum, respectively, at $30 \mathrm{~min}$. A similar study [23] had revealed about $87 \%$ overall particle removal efficiency when alum was used without coagulant aids in the treatment of slaughterhouse wastewater. In a separate study, Aguilar et al. [24] had reported that anionic polyacrylamide (coagulant aid) when used together with ferric sulphate $\left(\mathrm{Fe}_{2}\left(\mathrm{SO}_{4}\right)_{3}\right)$ and alum, significantly increased the quality of wastewater. Recently, a review by Aziz et al .[25] observed that inorganic salts such as alum and $\mathrm{FeSO}_{4}$ could be effectively applied for primary coagulation. During a study on the color removal efficiency of different alum dosage for two types of water (natural and tap water), Shan and Seyrig [26] observed that when spiked with humic substances, tap water had a better color removal rate than natural water at $100 \mathrm{mg} / \mathrm{L}$ alum dosage. The effectiveness of coagulation, flocculation, and coagulation plus flocculation on turbidity removal from natural stone processing wastewater using aluminum chloride $\left(\mathrm{AlCl}_{3}\right)$, ferric chloride $\left(\mathrm{FeCl}_{3}\right)$ and alum has been examined by [27]. It was observed that the coagulation and flocculation methods each applied separately were not sufficient in clarifying the wastewater, whereas the coagulation plus flocculation protocol was more effective in clarifying the wastewater than the other two applied protocols. The study further revealed that $\mathrm{AlCl}_{3}$ had the best turbidity removal efficiency rate than the $\mathrm{FeCl}_{3}$ and alum coagulants [27]. When the results obtained when tannery wastewater was treated through coagulation-flocculation using alum as primary coagulant, and cationic and anionic polymers as coagulant aids, was compared with the results of another experiment where alum was applied for coagulation-flocculation alone, it was observed that the addition of coagulant aid to alum resulted in more effluent turbidity removal rate than when alum was used alone. The study further noted that the cost of alum applied to treat one cubic meter of wastewater was significantly reduced when alum was used with coagulant aid than when alum was applied alone. The research concludes that a combination of alum and cationic/anionic polymers resulted in effective effluent turbidity removal efficiency than alum alone [28]. Most authors agree that the relative importance of the mechanism behind the coagulation-flocculation process is that it is based on intrinsic factors such as $\mathrm{pH}$, contact time, and coagulant dose [29]. Hence, Ukiwe and Alinnor [30] had studied the effect of coagulant dosage and contact time on turbidity removal in wastewater and found that by applying coagulant dose in the range of $50-200 \mathrm{mg} / \mathrm{L}$ of alum, approximately $90 \%$ of effluent turbidity was removed from the wastewater using $150 \mathrm{mg} / \mathrm{L}$ of alum in 20 
min. However, to obtain the same effluent turbidity removal from the wastewater using a coagulant aid (cationic polyacrylamide), approximately $200 \mathrm{mg} / \mathrm{L}$ of the chemical was added to the wastewater for $30 \mathrm{~min}$. These findings revealed that alum was a better coagulant than polyacrylamide in clarifying wastewater. In a separate study, Ukiwe et al. [31] had argued that alum is most effective as coagulant in reducing turbidity in wastewater compared to $\mathrm{FeSO}_{4}$ and ammonium aluminum sulphate. Previous studies by El-Gohary et al. [32] had compared the effectiveness of alum, $\mathrm{FeCl}_{3}$, and $\mathrm{FeSO}_{4}$ in treating wastewaters and concluded that alum was effective than $\mathrm{FeCl}_{3}$ and $\mathrm{FeSO}_{4}$ in removing natural organic matter from wastewaters. Several authors have been documented evidence revealing that alum is an established inorganic coagulant and the coagulant of choice in water and wastewater treatment [33],[34],[35],[36]. In this regard, Lynette et al. [37] demonstrated that application of alum to municipal wastewater was able to significantly improve the outflow water quality, while Papadopoulous et al. [38] also showed that alum was effective in removing organic matter from detergent wastewater. Other recognized inorganic chemical compounds commonly used in wastewater treatment include; activated alum (which contain about $9 \%$ sodium silicate), black alum (which contain activated carbon), and sodium aluminate (which is much more alkaline than alum) [39]. Notable approaches to the application of inorganic coagulants in wastewater treatment have been documented in studies relating to modeling and kinetics of coagulant chemicals such as alum, and $\mathrm{FeSO}_{4}, \mathrm{FeCl}_{3}$ [40],[41],[42],[43],[44],[45]. Published data of recent findings tend to support the idea that temperature affects coagulation kinetics and floc formation when inorganic coagulants are applied in treating water and wastewaters [46]. The investigation observed that low temperature slow down the coagulation process, whereas previous attempts by Ma et al. [47] had suggested that enhanced coagulation in wastewater treatment could be achieved using permanganate preoxidation where the manganese dioxide produced in-situ during permanganate preoxidation was essential in enhancing the coagulation-flocculation process.

Fe salts are beginning to attract attention as alternative coagulants to alum in wastewater treatment. Fe salts are preferred to alum because of concerns about Al concentration in treated water, efficient coagulation of Fe salts at low temperature, and the salts are capable of removing a wide range of organic matter from wastewater than alum. Also, Fe salts function well as coagulant in high acidic environment. They are less costly and have been found to posses $\mathrm{pH}$, coagulation ranges and floc characteristics similar to alum [48]. In spite of these recognized advantages, Fe salts are corrosive and often slow to dissolution, hence, high soluble Fe concentration are always present in effluents where Fe salts are used as coagulant [48]. The Fe salts commonly used as coagulant in water and wastewater treatment includes; $\mathrm{FeSO}_{4}, \mathrm{Fe}_{2}\left(\mathrm{SO}_{4}\right)_{3}, \mathrm{FeCl}_{3}$ [48]. Kim and Kang [49] investigated coagulation mechanisms and flocculation dynamics of Fe (III) salts and observed clear differences in coagulation mechanism and flocculation dynamics, especially noting that the flocculation dynamics was a reliable and sensitive indicator for coagulation mechanism. According to Aygun and Yilmaz [50], the use of $\mathrm{FeCl}_{3}$ as coagulant could be improved by the application of coagulant aid such as polyelectrolytes and clay minerals (bentonite and montmorillonite). In this regard, a study on coagulationflocculation to treat detergent wastewater using $\mathrm{FeCl}_{3}$ as coagulant observed that at optimal dosage of $2 \mathrm{~g} / \mathrm{L}$ of $\mathrm{FeCl}_{3}$ at $\mathrm{pH} 11$, the concentration of organic matter, expressed as COD, removed from the wastewater was approximately $71 \%$. However, addition of coagulant aids increased the removal efficiency of COD to $84 \%$ using clay minerals and $87 \%$ using polyelectrolytes. The authors concluded that addition of coagulant aids to $\mathrm{FeCl}_{3}$ provided higher removal efficiency of organic matter compared to coagulation using $\mathrm{FeCl}_{3}$ alone. Polyelectrolytes are available commercially as coagulant aids in the treatment of industrial wastewaters. They have added advantage over ordinary inorganic coagulants in that they are high quality chemical materials of high stability in aqueous environment [24]. A separate study also noted that coagulation-flocculation using $\mathrm{FeCl}_{3}$ is effective for the removal of surfactants and COD from industrial wastewater [51]. A published technical note by [52] demonstrated that $\mathrm{FeSO}_{4}$ and lime was successful in improving the quality of textile wastewater. Moreover, efficient turbidity removal could be achieved when $\mathrm{FeCl}_{3}$ and polyaluminum chloride are used together in the treatment process [53]. Optimum turbidity removal also yielded effective heavy metal $(\mathrm{Cu}, \mathrm{Zn}, \mathrm{Pb}, \mathrm{Cr}$ ) elimination [53]. Polyaluminum chloride has been shown to be an efficient coagulant than $\mathrm{FeCl}_{3}$ in treating petroleum wastewater [54]. In other findings, $\mathrm{FeCl}_{3}$ has been applied successfully to remove approximately $91 \%$ of COD in beverage industrial wastewater [55]. Interestingly, when polyelectrolytes such as a non-ionic polyacrylamide was used together with the $\mathrm{FeCl}_{3}$ in wastewater treatment, the concentration of COD removed increased to about $97 \%$. Organic polymers produced less sludge when they are applied as coagulant. They are inert to other ions in the water environment; hence, no precipitate is formed. When used in combination with inorganic salts such as $\mathrm{FeCl}_{3}$, the sludge volume generated during coagulationflocculation is reduced [56], [57], [58]. Reduction in sludge content leads to higher coagulation efficiency. A comparative investigation for removing colloidal particle from raw water using $\mathrm{FeCl} 3$, alum, and an anionic polymer revealed that $\mathrm{FeCl} 3$ produced better colloidal efficiency removal than alum and the anionic polymer [59]. Increasing the dosage of the three coagulants did not significantly increase colloidal particle removal efficiency from the raw water. Libecki and Dziejowski [60] pointed out that change in Fe (II) and Fe (III) ion content in solution of humic acids during coagulation is due to complex formation and redox reactions. Iron 
compounds found in water are subject to oxidation reaction determined by the $\mathrm{pH}$ of the water environment [61]. Iron ions found in water may have resulted from a reaction between Fe salts and dissolved organic substances leading to the formation of organic ferric complex. Formation of the complex lowers the $\mathrm{pH}$ of the solution, thus, increasing solution coloration [62]. Pre-hydrolysed Fe salts act to increase the pH of solutions and have been found successful in solving the problem often encountered with solution coloration. Developments on the application of Fe salts in coagulation-flocculation in wastewater treatment have since seen studies on the effects of $\mathrm{pH}$, ionic strength, and Fe-fulvic acid interactions on the kinetics of nonphotochemical iron transformations [63], coagulation of humic substances and dissolved organic matter with ferric salt [64], hydrolysis of inorganic Fe (III) salts [65], dissolved organic matter, Al, and Fe interactions in coagulation [66], and the role of natural organic matter in chemical and microbial reduction of ferric iron [67]. Further studies on the potential of $\mathrm{Fe}$ salts in coagulation-flocculation in water and wastewater treatment have been investigated by [68], [69], and [70].

\subsection{Electrocoagulation}

Electrocoagulation $(E C)$ also known as radio frequency diathermy or short wave electrolysis is fast becoming popular as an alternative method for the treatment of water and wastewater. The process is applied when removal of pollutant by chemical coagulation becomes difficult or impossible [71]. EC is an advanced economical water treatment process that has been shown to be effective in removing suspended solids, depolluting heavy metals and breaking down emulsifiers [72]. EC consists of pairs of sheet of metals used as electrodes (cathode and anode) and arranged using the principle of electrolysis. When the cathode electrode is immersed in the water or wastewater, the metal emits electrons which neutralize particles in the water by forming hydroxide complexes which agglomerates. Electrodes which initiate coagulation in the EC process are made up of metals such as Al or Fe. These metal cations dissolve at the anode according to the following equations:

$$
\begin{aligned}
& \mathrm{Fe}_{(\mathrm{s})} \rightarrow \mathrm{Fe}^{\mathrm{n+}}{ }_{(\mathrm{aq})}+\mathrm{ne} \\
& \mathrm{Al}(\mathrm{s}) \rightarrow \mathrm{Al}^{3+}{ }_{(\mathrm{aq})}+3 \mathrm{e}^{-}
\end{aligned}
$$

At the cathode, the following reaction occurs:

$$
2 \mathrm{H}_{2} \mathrm{O}+2 \mathrm{e}^{-} \rightarrow \mathrm{H}_{2}+2 \mathrm{OH}^{-}
$$

The chemistry behind the EC process in water in such that the positively charged ions are attracted to the negatively charged hydroxides ions producing ionic hydroxides with a strong tendency to attract suspended particles leading to coagulation.

Several studies have investigated the use of EC to improve the quality of industrial wastewater. Ni'am et al. [73] reported that a wastewater sample with initial COD of $1140 \mathrm{mg} / \mathrm{L}$ and turbidity of $491 \mathrm{NTU}$ had a removal efficiency of $65 \%$ COD and $95 \%$ turbidity when the wastewater was treated using EC. Butler et al. [74] noted that EC is a classic method for wastewater treatment since it is capable of reducing the cost and need for chemicals commonly used in coagulation. However, Bazrafshan et al. [75] demonstrated that using EC in treating dairy wastewater, the removal efficiency of COD, biological oxygen demand (BOD), and total suspended solids (TSS) increased with increasing applied voltage and reaction time. Several authors have applied EC successfully for treating dairy effluents wastewater [76],[77],[78]. In the treatment of slaughterhouse wastewater using EC and chemical coagulation, the influence of operating variables such as coagulant dose, electric potential, and reaction time were studied. Results obtained indicated that the rate of removal of organic compounds (COD and BOD), increased with increase in chemical coagulant dose and applied voltage. The study further observed that the combined EC and chemical coagulation process was superior to either chemical coagulation or EC treatment applied alone [79]. Related studies have been reported by [80] and [81]. It is important to note that EC is also effective for the treatment of a variety of industrial wastewaters such as vegetable oil wastewater [82], [83], and [84]. The process has been employed successfully to decontaminate waste streams of toxic cations and anions, as well as heavy metals [85]. In an $\mathrm{EC}$ process using $\mathrm{Al}$ as sacrificial anode to treat wastewater, the effect of applied voltage on the removal efficiency of trace metals was investigation. By varying the $\mathrm{pH}$ of the initial solution, the removal capacities of zinc $(\mathrm{Zn})$ and copper $(\mathrm{Cu})$ was increased from 20-40 volts in about $1 \mathrm{~h}$ [85]. Meanwhile, Bazrafshan et al. [86] had recently observed high removal rates of $\mathrm{Zn}$ and $\mathrm{Cu}$ from aqueous solutions using EC technique with $\mathrm{Fe}$ 
electrodes. Other studies have revealed similar results when EC with Fe electrodes was applied to decontaminate industrial wastewaters containing cadmium (Cd) [87]. Notable studies on the application of EC in treating industrial wastewaters have been documented on the performance and evaluation of EC for removal of chromium ( $\mathrm{VI})$ from synthetic chromium solutions using Fe and $\mathrm{Al}$ electrodes [88]. According to Adhoum et al. [89], applying EC in the treatment of wastewater containing metal ions $\left(\mathrm{Cu}^{2+}, \mathrm{Zn}^{2+}, \mathrm{Cr}^{6+}\right)$, it was observed that the most effective removal efficiency of the studied metals was achieved when the $\mathrm{pH}$ was maintained at 4.0 and 8.0 , respectively. Increasing the current density from 0.8 to $4.8 \mathrm{Adm}^{-2}$, enhanced the treatment rate of the wastewater without affecting the charge load required to reduce the metal ion concentration. The authors also revealed that the removal rate of $\mathrm{Cu}$ and $\mathrm{Zn}$ was five times quicker than that of $\mathrm{Cr}(\mathrm{VI})$ due to differences in the coagulation mechanism employed. In their contribution, Koparal and Ögütveren [90] concluded that electrochemical methods such as electroreduction and EC were effective in removing nitrates from water and wastewaters. The researchers observed that electroreduction and $\mathrm{EC}$ removed nitrates from wastewater ( $\mathrm{pH}$ range of 5.0-7.0 (electroreduction) and $\mathrm{pH}$ range of 9.0-11.0 (EC)) to allowable concentration limits. Applying both methods as a combined process to treat water revealed total removal rate of nitrate, though with higher energy consumption. Bazrafshan et al. [91] further investigated the removal of fluoride from water. In their opinion, using EC with Fe and Al electrodes, the most effective removal capacities of fluoride is achieved using applied voltage of 40 volts at $\mathrm{pH}$ 3.0. The authors shared the view that the EC technique has the potential to be used as a cost-effective method for the removal of anions from water and wastewaters.

A growing body of literature has been accumulating on the application of EC in the removal of organic matter from waste streams. Performance evaluation of EC in combination with thin layer chromatography for diazinon removal from water using Fe electrode at $\mathrm{pH} 3.0-10.0$ by applying a voltage in the range of $20-40$ volts has been reported by [92]. It was observed that initial concentration of diazinon affected the removal efficiency of the compound and higher removal efficiency was only achieved with higher electric potential (about 40 volts) and increase in reaction time $(60 \mathrm{~min})$. Other findings that tend to support the effectiveness of EC in the treatment wastewater containing organic substances include studies from Bazrafshan et al. [93], [94] who evaluated phenol removal by EC from aqueous solutions and removal of humic acid from wastewater using $\mathrm{EC}$ with $\mathrm{Fe}$ electrodes.

EC has also been employed to remove color substances from wastewater, especially, color caused by organic substances such as dyestuff. A comparative study of the effectiveness of chemical coagulation and $E C$ with $A l$ electrodes for decolorizing synthetic textile wastewater containing disperse red dye revealed that the removal yield of about $95 \%$ of the dye was enhanced when $\mathrm{EC}$ and chemical coagulation $\left(\mathrm{FeCl}_{3}\right.$ and alum) were used together at $\mathrm{pH}$ range of 4.0-8.0 for a dye concentration of $235 \mathrm{mg} / \mathrm{L}$ [95]. When EC is applied to treat wastewaters containing dyes, focused operational parameters to be monitored must include; electrolysis time, current density, initial $\mathrm{pH}$, inter electrode distance, initial dye concentration, and type of supporting electrode [96]. Un and Aytac [97] designed an EC reactor with the cylindrical Fe vat of the reactor serving as the cathode, while a packed bed of Fe wrappings was used as the anode. The reactor was designed to remove COD and colored substances from real textile wastewater. COD of the wastewater was reduced to approximately $99 \%$, while almost $100 \%$ of the color substance was removed. The study revealed that the unique designed reactor was very effective in treating textile wastewater to comply with legal requirements [97]. Phalakorkule et al. [98] demonstrated that approximately $95 \%$ of color could be removed using EC with an energy consumption of $1 \mathrm{kWh} / \mathrm{m}^{3}$ and dye concentration of $100 \mathrm{mg} / \mathrm{L}$, while Naje and Abbas [99] published data revealing that solution $\mathrm{pH}$, temperature, and dye auxiliaries are factors that influence the performance of the EC technique. To the extent that these factors are applied, would the removal efficiency of COD and BOD of textile wastewaters be substantially enhanced, most notable, when the EC process uses titanium/platinum anode, stainless steel cathode, and sodium chloride as the electrolyte [100]. Further contributions on EC application in treating textile wastewaters have been reported by [101], [102], and [103] in studies demonstrating that EC with Fe and Al electrodes, and combined electrochemical techniques are effective in treating textile wastewater. Other approaches on the application of EC investigated by researchers include; the fundamentals, and present and future perspectives of the process in water and wastewater treatment [104]. In these findings, the researchers observed that there has been relatively little effort dedicated to understanding the fundamental principles of the EC process with respect to design parameters and optimal performance. Nonetheless, most authors agree that for an EC process to be optimally effective in treating wastewaters, adequate knowledge of parameters such as wastewater type, $\mathrm{pH}$, current density, applied voltage, type of metal electrodes, number of electrodes, size of electrodes, and configuration of the metals is important since these variables ultimately affect the overall kinetics and removal efficiency of the EC reactor. 


\section{CONCLUSION}

The focus of the present study was to review various chemical and electrocoagulation methods involved in the treatment of water and wastewaters. It was observed that the basic principle guiding both treatment methods is particle charge destabilization. Fe and Al salts are two classic types of inorganic coagulants commonly used in chemical coagulation. These salts are involved in charge neutralization. Coagulant aids such as polymers are also used to increase density of flocs. New generation inorganic coagulants such as pre-hydrolyzed Fe/Al salts exhibit several advantages over traditional inorganic coagulants in that they are efficient, more effective, and relatively lower in cost. Comparatively, most researchers are of the opinion that Al salts are better coagulants than $\mathrm{Fe}$ salts in water and wastewater treatment. However, other authors argue that due to concerns of high concentrations of $\mathrm{Al}$ aqueous environment, and the fact that Fe salts operate effectively in water or wastewater with high acidity, as well as the ability of Fe salts to remove pollutants at varying temperatures, Fe salts are preferred over Al salts in water and wastewater treatment.

To overcome problems associated with chemical coagulation, EC has been advocated as a novel approach in removing suspended solids and color substances from wastewaters. Nevertheless, the general opinion of researchers is that for the $\mathrm{EC}$ process to be effective in treating wastewater, parameters such as $\mathrm{pH}$, current density, applied voltage, wastewater type, type of electrodes, number of electrodes, and size of the electrodes as well as configurations of metals used must be considered.

\section{REFERENCES}

[1] J.Q. Jiang, N.J.D. Graham. Pre-polymerised inorganic coagulants used for water and wastewater treatment. Chemistry \& Industry, 10, 389-391(1997).

[2] A.K. Anorld-Smith, R.M. Christie, C. Jolicoeur. Polyaluminum Silicate Sulphate: A New Coagulant for Potable and Wastewater Treatment. In H.H. Hahn and R. Klute (eds). Chemical Water \& Wastewater Treatment (II). Springer-Verlag, Berlin, Germany, 203-219 (1992).

[3] J.Q. Jiang, N.J.D. Graham, C. Harward. Comparison of polyferric sulphate with other coagulants for the removal of algae and algae-derived organic matter. Water Science and Technology, 27, 221-230 (1993).

[4] J.Q. Jiang, N.J.D. Graham. Preliminary evaluation of new kinds of pre-polymerised inorganic coagulants for surface water treatment. In: Proceedings of First International Conference on Reservoir Management and Water Treatment. May 19-23, Prague, Czech Republic (1997).

[5] H.X. Tang, W. Stumm. The coagulation behavior of Fe (III) polymer species. Water Research, 21, 115-121 (1987).

[6] H.X. Tang. Basic research on inorganic polymer flocculants. Environmental Chemistry, 10, 1-12 (1990).

[7] K.A. Gray, C.H. Yao, C.R. O'Melia. Polymeric inorganic coagulants. Journal of Amerecan Water Works Association, 87, 136-146 (1995).

[8] B.A. Dempsey, R. Ganho, C.R. O'Melia. The coagulation of humic substances by means of aluminium salts. Journal of American Water Works Association, 76, 141-145 (1984).

[9] J.E. Van Benschoten, J.K. Edzwald. Chemical aspects of coagulation using aluminium salts. I. Hydrolytic reactions of aluminium and polyaluminum chloride. Water Research, 24, 1519-1526 (1990).

[10] J.E. Van Benschoten, J.K. Edzwald. Chemical aspects of coagulation using aluminium salts. II. Coagulation of humic substances using aluminium and polyaluminum chloride. Water Research, 24, 1527-1535 (1990).

[11] D. Wang, H. Tang. Modified inorganic polymer flocculant-PFSi: Its preparation, characterization and coagulation behaviour. Water Research, 35, 3418-3428 (2001).

[12] N.D. Tzoupanou, A.I. Zouboulis. Coagulation-flocculation processes in water/wastewater treatment: The application of new generation of chemical reagents. In: Proceedings of $6^{\text {th }}$ IASME/WSEAS International Conference on Heat Transfer, Thermal Engineering and Environment. August 20-22, Rhodes, Greece (2008).

[13] B.Y. Gao, H.H. Hahn, E. Hoffmann. Evaluation of aluminium silicate polymer composite as a coagulant for water treatment. Water Research, 36, 3573-3581 (2002). 
[14] T. Hasegawa, K. Hashimoto, T. Oritsuka, K. Goto, N. Tambo. Characteristics of metal polysilicate coagulants. Water Science \& Technology, 23, 1713-1722 (1990).

[15] A.I. Zouboulis, N.D. Tzoupanos. Polyaluminum silicate chloride-a systematic study for the preparation and application of an efficient coagulant for water or wastewater treatment. Journal of Hazardous Materials, 162, 1379-1389 (2009).

[16] P.C. Chang, F.G. Chi, R.F. Yu, P.Z. Shi. Evaluating the coagulants of polyaluminum silicate chlorides on turbidity removal. Separation Science \& Technology, 41, 297-309 (2005).

[17] A.I. Zouboulis, N.D. Tzoupanos, P.A. Moussas. Inorganic pre-polymerised coagulants: Current status and future trends. In Proceedings of $3^{\text {rd }}$ IASME/WSEAS International Conference. July 24-26, Nikolaos, Greece (2007).

[18] N.D. Tzoupanou, A.I. Zouboulis, Y.C. Zhao. The application of novel coagulant reagent (polyaluminum silicate chloride) for the post-treatment of landfill leachates. Chemosphere, 73, 729-736 (2008).

[19] Y.H. Song, Z.K. Luan, H.X.Tang. Preparation and characterization of polyaluminum silicate chloride coagulant. Environmental Technology, 24, 319-327 (2003).

[20] H. Tang, B. Shi. The characteristics of composite flocculants synthesized with inorganic polyaluminum and organic polymers. In: Proceedings of the $10^{\text {th }}$ Gothenburg Symposium on Chemical Water and Wastewater Treatment VII. June 17-19, Gothenburg, Sweden (2002).

[21] B.Y. Gao, Y. Wang. Q.Y. Yue. The chemical species distribution of aluminium composite flocculants prepared from polyaluminum chloride (PAC) and polydimethyldiallylammonium chloride (PDMDAAC). Acta Hydrochimica et Hydrobiologica, 33, 365-371 (2005).

[22] J.P Kushwaha, S.V. Chandra, I.D. Mall. Treatment of dairy wastewater by inorganic coagulants: Parametric and disposal studies. Water Research, 44, 5867-5874 (2010).

[23] M.I. Aquilar, J. Sáez, M. Llorens, A. Soler, J.F. Ortuño. Particle size distribution in slaughterhouse wastewater before and after coagulation-flocculation. Environmental Progress, 22, 183-188 (2003).

[24] M.I. Aquilar, J. Sáez, M. Llorens, A. Soler, J.F. Ortuño, V. Meseguer, A. Fuentes. Improvement of coagulation-flocculation process using anionic polyacrylamide as coagulant aid. Chemosphere, 58, 47-56 (2005)

[25] A.H. Aziz, S. Alias, F. Assari, M.N. Adlan. The use of alum, ferric chloride and ferrous sulphate as coagulants in removing suspended solids, color and COD from semi-aerobic landfill leachate at controlled pH. Waste Management Research, 25, 556-565 (2007).

[26] W. Shan, G. Seyrig. Coagulation and flocculation color removal. ENE 806 Project Report 2. College of Engineering, Michigan State University (2007).

[27] B. Ersoy, I. Tosun, A. Günay, S. Dikmen. Turbidity removal from wastewaters of natural stone processing by coagulation/flocculation methods. CLEAN-Soil, Air, Water, 37, 225-232 (2009).

[28] S. Haydar, J.A. Aziz. Coagulation-flocculation studies of tannery wastewater using combination of alum with cationic and anionic polymers. Journal of Hazardous Materials, 168, 1035-1040 (2009).

[29] J.M. Duan, J. Gregory. Coagulation by hydrolysing metal salts. Advances in Colloid and Interface Science, 100, 475-502 (2003).

[30] L.N. Ukiwe, J.I. Alinnor. Assessment of polyacrylamide and aluminium sulphate coagulants in turbidity removal in wastewater. Terrestrial and Aquatic Environmental Toxicology, 6, 132-135 (2010).

[31] L.N. Ukiwe, I.C. Iwu, M. Chijioke-Okere. The role of inorganic metal salts in wastewater clarification. Journal of Advances in Chemistry, 4, 318-322 (2013).

[32] F. El-Gohary, A. Tawfik, U. Mahmoud. Comparative study between chemical coagulation/precipitation versus coagulation/dissolved air flotation for pre-treatment of personal care products wastewaters. Desalination, 252, 106-112 (2010).

[33] B.A. Dempsey, R.M. Ganho, C.R. O'Melia. The coagulation of humic substances by means of aluminium salts. Journal of American Water Works Association, 76, 141-149 (1984).

[34] J.Q. Jiang, N.J.D. Graham. Enhanced coagulation using Al/Fe (III) coagulants: Effects of coagulant chemistry on the removal of color-causing NOM. Environmental Technology, 17, 937-950 (1996). 
[35] M.K. Korbutowicz. Effect of Al coagulant type on natural organic matter removal efficiency in coagulation/ultrafiltration process. Desalination, 185, 327-333 (2005).

[36] B. Libecki, J. Dziejowski. Interactions of aluminium and iron (III) salts with humic acids in a model alkaline solution. Polish Journal of Natural Science, 23, 681-686 (2008).

[37] L.M. Malecki-Brown, J.R. White, H.Brix. Alum application to improve water quality in a municipal wastewater treatment wetland: Effects on macrophyte growth and nutrient uptake. Chemosphere, 79, 186-192 (2010).

[38] A. Papadopoulos, C. Savvides, M. Loizidis, K.J. Haralambous, M. Loizidou. An assessment of the quality and treatment of detergent wastewater. Water Science and Technology, 36, 377-381 (1997).

[39] T. Tripathy, D.B. Ranjan. Flocculation: A new way to treat wastewater. Journal of Physical Sciences, 10, 93-127 (2006).

[40] J. van Leeuwen, M. Holmes, C. Heidenreich, R. Daly, I. Fisher, G. Kastl, A. Sathasivan, D. Bursill. Modelling the application of inorganic coagulants and $\mathrm{pH}$ control reagents for removal of organic matter from drinking waters. Available online; http//:www.mssanz.org

[41] R.B. Moruzzi, S.C. de-Oliveira. Mathematical modelling and analysis of the flocculation process in chambers in series. Bioprocess and Biosystems Engineering, 8, 791-794 (2012).

[42] V.I. Ugonabo, M.C. Menkiti, D.O. Onukwuli. Effect of coag-flocculation kinetics on Telfairia occidentalis seed coagulant (TOC) in pharmaceutical wastewater. International Journal of Multi-displinary Sciences and Engineering, 3, 25-33 (2012).

[43] V.I. Ugonabo, M.C. Menkiti, E.C. Osoka, C.U. Atuanya, O.D. Onukwuli. Kinetic modelling and functional parameters evaluation of mass transfer rate on bio-coagulant interface in pharmaceutical industry effleuent. International Journal of Basic \& Applied Sciences, 13, 33-47 (2013).

[44] M.C. Menkiti, P.K. Igbokwe, F.X.O. Ugodulunwa, O.D. Onukwuli. Rapid coagulation-flocculation kinetics of coal effluents with high organic content using blended and unblended chitin derived coagulants (CSC). Research Journal of Applied Sciences, 3, 317-323 (2008).

[45] L.N. Ukiwe, C.I.A. Nwoko, M. Okere-Chijioke. Kinetic study of aluminium sulphate and ammonium aluminium sulphate coagulants in wastewater treatment. Journal of Advances in Chemistry, 3, 222-228 (2013).

[46] F. Xiao, J.H. Huang, B. Zhang, C. Cui. EEfects of low temperature on coagulation kinetics and floc surface morphology using alum. Desalination, 237, 201-213 (2009).

[47] J. Ma, G.B. Li, Z.L. Chen, G.R. Xu, G.Q. Cai. Enhanced coagulation of surface waters with high organic content by permanganate preoxidation. Water Science and Technology, 1, 51-61 (2001).

[48] O.P. Sahu, P.K. Chaudhari. Review on chemical treatment of industrial wastewater. Journal of Applied Science and Environmental Management, 17, 241-257 (2013).

[49] J. Kim, L. Kang. Investigation of coagulation mechanism with Fe (III) salt using Jar tests and flocculation dynamics. Environmental Engineering Research, 3, 11-19 (1998).

[50] A. Aygun, T. Yilmaz. Improvement of coagulation-flocculation process for treatment of detergent wastewater using coagulation aids. International Journal of Chemical and Environmental Engineering, 1, 97-101 (2010).

[51] M.A. Aboulhassan, S. Souabi, A. Yaacoubi, M.Baudu. Removal of surfactant from industrial wastewaters by coagulation-flocculation process. International Journal of Environmental Science and Technology, $\mathbf{3}$ 327-332 (2006).

[52] D. Georgiou, A. Aivazidis, J. Hatiras, K. Gimouhopoulos. Treatment of cotton textile wastewater using lime and ferrous sulphate. Water Research, 37, 2248-2250 (2003).

[53] A.G. Samrani, B.S. Lartiges, F. Villiéras. Chemical coagulation of combined sewer overflow: Heavy metal removal and treatment optimization. Water Research, 42, 951-960 (2007).

[54] H. Farajnezhad, P. Gharbani. Coagulation treatment of wastewater in petroleum industry using polyaluminum chloride and ferric chloride. International Journal of Research and Reviews in Applied Sciences, 13, 306-311 (2012). 
[55] O.S. Amuda, I.A. Amoo. Coagulation/flocculation process and sludge conditioning in beverage industrial wastewater treatment. Journal of Hazardous Materials, 141, 778-783 (2006).

[56] O.S. Amuda, I.A. Amoo, O.O. Ajayi. Performance optimization of coagulation/flocculation in the treatment of wastewater from a beverage industry. Journal of Hazardous Materials, B129, 69-72 (2006).

[57] S. Pattabi, K. Ramasami, K. Selvam, P. Swaminathan. Influence of polyelectrolytes on sewage water treatment using inorganic coagulants. Indian Journal of Environmental Protection, 20, 499-507 (2000).

[58] A.A. Tatsi, A.I. Zouboulis, K.A. Matis, P. Samaras. Coagulation-flocculation pretreatment of sanitary landfill leachates. Chemosphere, 53, 737-744 (2003).

[59] A. Koohestanian, M. Hosseini, Z. Abbasian. The separation method for removing of colloidal particles from raw water. American-Eurasian Journal of Agriculture and Environmental Science, 4, 266-273 (2008).

[60] B. Libecki, J. Dziejowski. Changes in iron (II) and iron (III) content in a solution of humic acids during coagulation by means of monomeric iron (III) salts. Polish Journal of Environmental Studies, 19, 10891093 (2010).

[61] W. Feng, D. Nansheng. Photochemistry of hydrolytic iron (III) species and photo-induced degradation of organic compounds: A mini review. Chemosphere, 41, 1137-1149 (2000).

[62] T. Kowalski. On the chemical parameters of water pollutants and their effect on the choice of coagulants. Ochrona Środowiska, 4, 59-62 (1995).

[63] J.M. Pullin, S. Cabaniss. The effects of $\mathrm{pH}$, ionic strength, and iron-fulvic acid interactions on the kinetics of non-photochemical iron transformations. I. Iron (II) oxidation and iron (III) colloid formation. Geochimica et Cosmochimica Acta, 67, 4067-4088 (2003).

[64] A.V. Jung, T. Chanudet, J. Ghanbaja, B.S. Lartiges, B.L. Bersillon. Coagulation of humic substances and dissolved organic matter with a ferric salt: An electron energy loss spectroscopy investigation. Water Research, 39, 3849-3862 (2005).

[65] M.C. Flynn. Hydrolysis of inorganic iron (III) salts. Chemical Reviews, 84, 31-41 (1984).

[66] K.G.J. Nierop, B. Jansen, J.M. Verstraten. Dissolved organic matter, aluminium and iron interactions: Precipitation induced by metal carbon ratio, $\mathrm{pH}$, and competition. Science of the Total Environment, 300, 201-206 (2002).

[67] J. Chen, B. Gu, R.A. Royer, W.D. Burgow. The roles of natural organic matter in chemical and microbial reduction of ferric iron. Science of the Total Environment, 307, 167-172 (2003).

[68] A.G. El-Samrani, B.S. Lartiges, E. Montargés-Pelletier, V. Kazpard, O. Barrès, J. Ghanbaja. Clarification of municipal sewage with ferric chloride: The nature of coagulant species. Water Research, 38, 756-768 (2004).

[69] J. Gregory, V. Dupont. Properties of flocs produced by water treatment coagulants. Water Science and Technology, 44, 231-236 (2001).

[70] A. Amirtharajah, K.E. Denneth, A.A. Studstill. Ferric chloride coagulation for removal of dissolved organic matter and trihalomethane precursors. Water Science and Technology, 27, 113-121 (1993).

[71] J. Rodriguez S. Stopić, G. Krause, B. Friedrich. Feasibility assessment of electrocoagulation towards a new sustainable wastewater treatment. Environmental Science and Pollution Research, 14, 477-482 (2007).

[72] C.L. Lai, S.H. Lin. Treatment of chemical/mechanical polishing wastewater by electrocoagulation system performances and sludge settling characteristics. Chemosphere, 54, 235-242 (2003).

[73] M.F. Ni'am, F. Othman, J. Sohaili, Z. Fauzia. Removal of COD and turbidity to improve wastewater quality using electrocoagulation technique. The Malaysian Journal of Analytical Sciences, 11, 198-205 (2007).

[74] E. Butler, Y.T. Hung, R.Y. Yeh, M.S. Al-Ahmad. Electrocoagulation in wastewater treatment-A review. Water, 3, 495-525 (2011).

[75] E. Bazrafshan, H. Moein, F.K. Mostafapour, S. Nakhaie. Application of electrocoagulation process for dairy wastewater treatment. Journal of Chemistry, 2013, 1155-1163 (2013). 
[76] I.A. Şengil, M. Özacar. Treatment of dairy wastewater by electrocoagulation using mild steel electrodes. Journal of Hazardous Materials, 137, 1197-1205 (2006).

[77] S. Tchamango, C.P. Nanseu-Njiki, E. Ngameni, D. Hadjier, A. Darchen. Treatment of dairy effluents by electrocoagulation using aluminium electrodes. Science of the Total Environment, 408, 947-952 (2010).

[78] M. Kobya, H. Hiz, E. Senturk, C. Aydiner, E. Demirbas. Treatment of potato chips manufacturing wastewater by electrocoagulation. Desalination, 190, 201-211 (2006).

[79] E. Bazrafshan, F.K. Mostafapour, M. Farzadkia, K.A. Ownagh, A.H. Mahvi. Slaughterhouse wastewater treatment by combined chemical coagulation and electrocoagulation process. Plos ONE, 7, e40108 (2012)

[80] Ü Tezcan, A.S. Koparal, B.Ü. Öğütveren. Hybrid processes for the treatment of cattle-slaughterhouse wastewater using aluminium and iron electrodes. Journal of Hazardous Materials, 164, 580-586 (2009).

[81] X. Chen, G. Chen, P.L. Yue. Separation of pollutants from restaurant wastewater by electrocoagulation. Separation and Purification Technology, 19, 65-76 (2000).

[82] Ü Tezcan, A.S. Koparal, B.Ü. Öğütveren. Electrocoagulation of vegetable oil refinery wastewater using aluminium electrodes. Journal of Environmental Management, 90, 428-433 (2009).

[83] L.S. Calvo, J.P. Leclerc, G. Tnguy, M.C. Cames, G. Paternotte, G. Valentin, A. Rostan, F. Lapicque. An electrocoagulation unit for the purification of soluble oil wastes of high COD. Environmental Progress, 22, 57-65 (2003).

[84] M. Carmona, M. Khemis, J.P. Leclerc, F. Lapicque. A simple model to predict the removal of oil suspension from water using the electrocoagulation technique. Chemical Engineering Science, 61, 1237 1246 (2006).

[85] J. Nouri, A.H. Mahvi, E. Bazrafshan. Application of electrocoagulation process in removal of zinc and copper from aqueous solutions by aluminium electrodes. International Journal of Environmental Research, 4, 201-208 (2010).

[86] E. Bazrafshan, A.H. Mahvi, M.A. Zazouli. Removal of zinc and copper from aqueous solutions by electrocoagulation technology using iron electrodes. Asian Journal of Chemistry, 23, 5506-5510 (2011).

[87] E. Bazrafshan, A.H. Naseri, A.R. Mesdaghinia, F. Vaezi, S.H. Nazmara. Removal of cadmium from industrial effluents by electrocoagulation process using iron electrodes. Iranian Journal of Environmental Health Science and Engineering, 3, 261-266 (2006).

[88] E. Bazrafshan, A.H. Mahvi, S. Naseri, A.R. Mesdaghinia. Performance evaluation of electrocoagulation process for removal of chromium (VI) from synthetic chromium solutions using iron and aluminium electrodes. Turkish Journal of Engineering and Environmental Sciences, 32, 59-66 (2008).

[89] N. Adhoum, L. Monser, N. Bellakhal, J.E.Belgaied. Treatment of electroplating wastewater containing $\mathrm{Cu}^{2+}, \mathrm{Zn}^{2+}$ and $\mathrm{Cr}(\mathrm{VI})$ by electrocoagulation. Journal of Hazardous Materials, 112, 207-213 (2004).

[90] A.S. Koparal, B.Ü. Öğütveren. Removal of nitrate from water by electroreduction and electrocoagulation. Journal of Hazardous Materials, 89, 83-94 (2002).

[91] E. Bazrafshan, K.A. Ownagh, A.H. Mahvi. Application of electrocoagulation process using iron and aluminium electrodes for fluoride removal from aqueous environment. E-Journal of Chemistry, 9, 22972306 (2012).

[92] E. Bazrafshan, A.H. Mahvi, S. Naseri, M. Shaieghi. Performance evaluation of electrocoagulation process for diazinon removal from aqueous environments by using iron electrodes. Iranian Journal of Environmental Health Science and Engineering, 4, 127-132 (2007).

[93] E. Bazrafshan, H. Biglari, A.H. Mahvi. Phenol removal by electrocoagulation process from aqueous solutions. Fresenius Environmental Bullentin, 21, 364-371 (2012).

[94] E. Bazrafshan, H. Biglari, A.H. Mahvi. Humic acid removal from aqueous environments by electrocoagulation process using iron electrodes. E-Journal of Chemistry, 9, 2453-2461 (2012).

[95] B. Merzouk, B. Gourich, K. Madani, C. Vial. Removal of a disperse red dye from synthetic wastewater by chemical coagulation and continuous electrocoagulation. A comparative study. Desalination, 272, 246253 (2011). 
[96] S. Aoudj, A. Khelifa, N. Droiche, M. Hecini, H. Hamitouche. Electrocoagulation process applied to wastewater containing dyes from textile industry. Chemical Engineering and Processing: Process Intensification, 49, 1176-1182 (2010).

[97] T.U. Un, E. Aytac. Electrocoagulation in a packed bed reactor-complete treatment of color and COD from real textile wastewater. Journal of Environmental Management, 123, 113-119 (2013).

[98] C. Phalakorkule, S. Polgumhang, W. Tongdaung, B. Karaka, T. Nuyut. Electrocoagulation of blue reactive, red disperse and mixed dyes, and application in treating textile effluent. Journal of Environmental Management, 91, 918-926 (2010).

[99] A.S. Naje, S.A. Abbas. Electrocoagulation technology in wastewater treatment: A review of methods and applications. Civil and Environmental Research, 3, 29-42 (2013).

[100] A.G. Vlyssides, D. Papaioannou, M. Loizidou, P.K. Karlis, A.A. Zopas. Testing an electrochemical method for treatment of textile dye wastewater. Waste Management, 20, 569-574 (2000).

[101] M. Kobya, O.T. Can, M. Bayramoglu. Treatment of textile wastewaters by electrocoagulation using iron and aluminium electrodes. Journal of Hazardous Materials, B100, 163-178 (2003).

[102] O.T. Can, M. Kobya, E. Demirbas, M. Bayramoglu. Treatment of the textile wastewater by combined electrocoagulation. Chemosphere, 62, 181-187 (2006).

[103] S.H. Lin, C.F. Peng. Treatment of textile wastewater by electrochemical method. Water Research, 28, 277-282 (1994).

[104] M.Y.A Mollah, P. Morkovsky, J.A.G. Gomes, M. Kesmez, J. Parga, D.L. Cocke. Fundamentals, present and future perspectives of electrocoagulation. Journal of Hazardous Materials, 114, 199-210 (2004). 